\title{
A SURVEY OF 400 CASES OF CEREBRAL PALSY IN CHILDHOOD
}

\author{
BY \\ PATRIA ASHER and F. ELEANOR SCHONELL \\ From the Department of Paediatrics and Child Health, University of Birmingham, and the \\ Birmingham Institute of Child Health
}

(Received for Publcation March 31, 1950)

In recent years cerebral palsy, a previously neglected subject, has attracted much attention, at first in the U.S.A. and, more recently, in this country. In many districts plans are being made for the treatment and education of affected children. Before such plans can be effective we need to know how many children with cerebral palsy are to be expected in any community, and what will be the nature of their physical and mental handicap. Hitherto information of this nature has been scanty, and estimates of the incidence of cerebral palsy have been based on the numbers found in institutions, those presenting for treatment at special centres, or cases detected during routine school medical inspections.

In making this survey of cerebral palsy among children in Birmingham and the neighbouring counties (Warwickshire, Staffordshire, and Worcestershire) our aim was to locate and examine every case in the area. We did not achieve this aim for, at the time of writing (October, 1949) there are 131 cases awaiting examination, and doubtless there are many others as yet unknown to us, especially among very young children. Still, we believe that we are now in a position to make a rough estimate of the incidence of cerebral palsy, at least in certain towns covered by our survey. Moreover, our sample, though not yet complete, we believe to be representative. We made every effort to see every case reported by general practitioners, specialists, school medical officers, welfare officers, school teachers and by the parents themselves; we searched mental defective institutions, special schools, and hospitals for cases we might otherwise have missed. We have seen every type of case, from the hopeless quadriplegic ament, bedridden in an institution, to the mildest hemiplegic or paraplegic attending a normal school. The physical and mental examination of these children has enabled us to estimate the relative incidence of the different types of cerebral palsy, and to assess the physical and mental handicap suffered by these children. Finally, our results enable us to make certain observations on the aetiology of cerebral palsy.

\section{ORGANIZATION OF THE SURVEY}

In the summer of 1947 Professor Smellie wrote to all the doctors in Warwickshire, Staffordshire, Worcestershire, Shropshire, and Herefordshire, asking them to report any cases of cerebral palsy known to them. About $70 \%$ of these doctors replied, and a register was compiled of the cases they reported. Later, many more names were sent in, usually by medical officers of health and school medical officers. The great majority of the children we saw came from the three first named counties; a few came from outside the Midlands.

At the time of writing there are 587 cases on the register, of whom we have seen 466 . Sixty-six of those examined proved to be suffering from some condition other than cerebral palsy-usually uncomplicated mental deficiency. The remaining $\mathbf{4 0 0}$ form the basis of this communication.

\section{THE INCIDENCE OF CEREBRAL PALSY}

In four cities-Birmingham, Coventry, Stoke-onTrent, and Walsall-we saw enough cases to make an estimate of the incidence of cerebral palsy among school-age children in these cities of some value. We did not see enough under-fives to make such an estimate for the younger children.

The low incidence for Stoke-on-Trent shown in Table 1 is due to the fact that we saw no low grade defectives there, where nearly all our cases were referred by the school medical officer.

We can make a better estimate of the incidence by including $85 \%$ of the cases referred but not yet seen, as we found that just over $85 \%$ of the cases we 
TABuE 1

Incidence of Cerebral Palsy in the School-age Population of Four Cimes

\begin{tabular}{l|ccc|c}
\multicolumn{1}{c|}{ City } & $\begin{array}{c}\text { Population } \\
\text { (5-15 years) }\end{array}$ & $\begin{array}{c}\text { No. of Cases } \\
\text { of C.P. } \\
\text { (5-15 years) }\end{array}$ & $\begin{array}{c}\text { Incidence } \\
\text { per 1,000 }\end{array}$ \\
\hline Birmingham & $\ldots$ & 144,000 & 110 & $0 \cdot 76$ \\
Coventry & $\ldots$ & 32,836 & 31 & $0 \cdot 94$ \\
Stoke-on-Trent & 39,583 & 23 & $0 \cdot 58$ \\
Walsall & $\ldots$ & 17,330 & 13 & $0 \cdot 77$ \\
& & & \\
\hline
\end{tabular}

did see- 400 out of 466 proved to be cases of cerebral palsy. As the additional numbers are small the figures for the smaller towns have been combined.

TABLE 2

Estimated Incidence of Cerebral Palsy

\begin{tabular}{|c|c|c|c|c|c|}
\hline City & 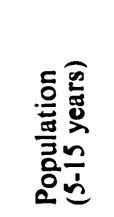 & 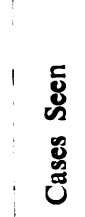 & 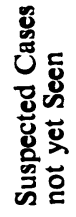 & 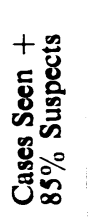 & 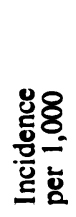 \\
\hline $\begin{array}{l}\text { Birmingham } \\
\text { Coventry } \\
\text { Stoke-on- } \\
\text { Trent } \\
\text { Walsall }\end{array}$ & 144,000 & 110 & 26 & $132 \cdot 1$ & 0.9 \\
\hline
\end{tabular}

In view of the admirable cooperation of general practitioners, specialists, and public health officers in these areas we think it unlikely that any great number of cases of school age escaped us. Probably the incidence of cerebral palsy among these children is in the region of 1 per 1,000 . This is very much less than Phelps's (1941a) estimate of six children with cerebral palsy per 100,000 total population per year; this would mean 600 cases aged 5-15 years in Birmingham (population one million) where we estimate that about 150 school-age children are affected. Phelps, however, does not give the data on which his figures are based. Our results are similar to those of Professor Mackintosh who, in an address to the British Council for the Welfare of Spastics (1946), estimated that there were $1 \cdot 2$ cases of cerebral palsy per 1,000 children of school age in Scotland.

\section{METHODS OF EXAMINATION AND RESULTS}

A careful history was taken from the mother whenever possible; a questionnaire was sent to the mothers of children seen in institutions if they could not attend for interview. The history of the child's birth was not checked by reference to hospital or other records; Evans (1948) found that such records usually confirmed the mother's story. In cases of acquired cerebral palsy records of the child's stay in hospital, if any, at the time of the original illness, were obtained wherever possible.

Every child was examined clinically by one of us (P.A.) and, of those over 3 years old, all but two were seen by the psychologist for an assessment of intelligence (carried out by F.E.S. in all but ten cases). Blood for Rh and Wassermann tests was taken in some instances.

Our $\mathbf{4 0 0}$ cases fall into the following groups:

A. Congenital cerebral palsy

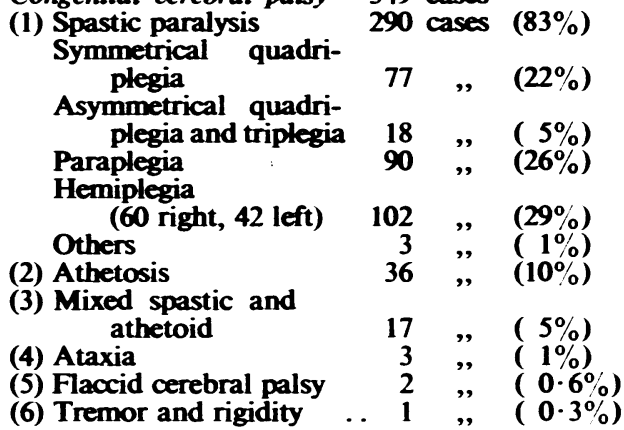

$$
\begin{aligned}
& 349 \text { cases } \\
& 290 \text { cases }(83 \%) \\
& 77 \quad, \quad(22 \%) \\
& 8 \quad, \quad\left(\begin{array}{c}
5 \% \\
56 \%
\end{array}\right) \\
& 3 \quad, \quad(29 \%) \\
& 36, \quad(10 \%)
\end{aligned}
$$

(2) Athetosis

(5) Flaccid cerebral palsy $2, " \quad(0.6 \%)$

(6) Tremor and rigidity $\ldots 1$

B. Acquired cerebral palsy (including
kernicterus)

(1) Kernicterus 19

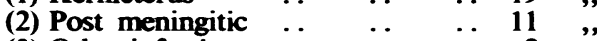

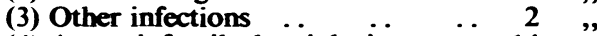

(4) Acute infantile hemiplegia $\ldots 14$,"

(5) Progressive degenerative spastic

$\begin{array}{cccccc}\text { paralysis } & \ldots & \ldots & \ldots & 4 & \text {, }\end{array}$

\section{A. CONGENITAL CEREbral Palsy}

\section{History and Clinical Findings}

History. In a large number of these cases there was a history of difficult birth, and the neonatal period had been stormy. (These facts will be discussed in detail later.) The neonatal period once over, the child seemed to develop normally until the age of 6 to 9 months, when he was noticed to be backward in sitting up. Backwardness in passing the usual milestones was the first sign of the trouble in the vast majority of cases. In a few cases abnormalities of tone or posture were noticed from the earliest stages. The difference between the two hands makes for the earlier diagnosis of hemiplegia than of other types of cerebral palsy; thus in $34 \%$ of hemiplegics some abnormality was noted before the age of 6 months, and in only $11 \%$ of paraplegics; for athetoids and quadriplegics the figures are $20 \%$ 
and $30 \%$ respectively. The diagnosis of cerebral palsy was usually made during the second year of life, and subsequent development depended upon the nature of the child's affliction.

Among the children whom we examined we found the following symptoms.

Difficulty in Walking. This was the commonest symptom in most groups. Thus, of 320 cases over the age of 3 years $102(32 \%)$ could not walk and 42 $(13 \%)$ could only just walk. The proportion was naturally highest among the quadriplegic spastics and athetoids.

Difficulty in Using the Hands. This was very noticeable among the athetoids, even the milder ones, and among the severer spastics. Of the athetoids over the age of 3 years $24 \%$ could not feed themselves; for spastic quadriplegics the figure was $31 \%$ but many of these were low grade defectives. Few children with other types of spasticity could not feed themselves.

Speech Difficulties. These were most common among the athetoids; spastics could usually talk reasonably well unless the intelligence was low. Of athetoids, $27 \%$ could not speak and another $25 \%$ had a severe speech defect. The figures for spastic quadriplegics were $37 \%$ and $15 \%$, but nearly all those who were speechless were idiots. Hemiplegics and paraplegics rarely had severe speech defects. We saw one case of motor aphasia, that of a boy with spastic quadriplegia; he had a cervical spina bifida and a meningocele had been operated on when he was a few days old.

Slobbering and Grimacing. These habits were practically confined to the athetoids.

Fits. Almost a quarter of spastic quadriplegics and hemiplegics were epileptic $(23.8 \%$ and $24 \cdot 2 \%$ respectively). Epilepsy was rare in other groups, although about one child in eight of the whole series had had an occasional convulsion.

The frequency of fits among hemiplegics has often been noted (e.g., Ford, 1944). We found, however, that epilepsy was equally common among the more severe cases of symmetrical spastic paralysis, where it was often associated with idiocy. Of spastic paraplegics only $3 \%$ were epileptic and only $4 \%$ of athetoids.

Incontinence. Incontinence was nearly always a sign of low intelligence; $14 \%$ of all cases over the age of 3 years were frequently or always incontinent and two-thirds of these were idiots.

Visual Defects. Refractive errors were probably common but we do not know the exact incidence. Of all cases $25 \%$ had a squint. Squints were commonest among the spastic quadriplegics $(33 \%)$, least common among hemiplegics $(16.5 \%)$ and athetoids (14\%).
Deafness. Deafness was noted by the mother in 10 out of 55 athetoids (including cases of kernicterus) and in only three of all the other cases. Audiometry, however, shows that there is often some hearing loss even in those who do not seem deaf to their associates.

General Condition. Although the great majority of these children were well looked after by devoted parents, nearly all of them were undersized and underweight.

Head Circumference. The head was commonly on the small side. The more severe the other signs of brain damage the smaller, on the average, was the head. Thus, there were 14 microcephalics, all of whom were low grade defectives with a severe degree of paralysis; 11 were spastic, two were athetoid, and one had a mixed type of paralysis. Of spastic quadriplegics $53 \%$ were microcephalic or had head circumferences more than one inch below the average for the age, $29 \%$ of athetoids, $27 \%$ of hemiplegics, and only $19 \%$ of paraplegics; among the last two groups none were microcephalic. There were 12 hydrocephalics; seven had a paraplegia, three quadriplegia, and two hemiplegia. In one case the hydrocephalus was associated with a cervical spina bifida.

Other Congenital Abnormalities. In nine cases $(2 \cdot 6 \%)$ there were other congenital abnormalities.

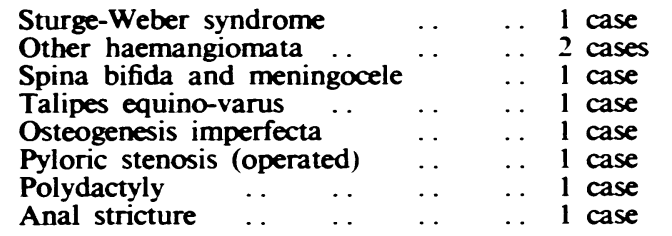

One of these (anal stricture) was associated with athetosis, the others with spastic paralysis.

This incidence is similar to that found by Malpas (1937) in a series of 13,964 consecutive births $(2 \cdot 1 \%)$.

There were also two cases of asthma and one of migraine; the latter was interesting in that the child had a right hemiplegia and migraine associated with right sided teichopsia.

\section{Neurological Findings}

Spastic Paralysis. This was much the largest group in our series (290 cases). The commonest type of spastic paralysis was a symmetrical quadriplegia ( 77 cases) or paraplegia ( 90 cases). The term diplegia has been variously used to cover either or both these conditions; to avoid confusion it will not be employed here. The symmetrical quadriplegics and paraplegics have been considered separately, but the distinction between them is an arbitrary one, many quadriplegics having an almost 
imperceptible lesion of the upper limbs. The combined group (167 cases) forms a continuous series from the mildest paraplegic to the severest quadriplegic - often a microcephalic idiot.

In nearly all the quadriplegics the lower limbs were more severely affected than the upper. In both quadriplegics and paraplegics adductor spasm of the thighs was commonly present, leading to ' scissors gait' if the child could walk. The knees might be extended or flexed; the feet were nearly always plantar flexed. In very young children who cannot walk these deformities are often not apparent when the child is lying down; if, however, he is supported in the upright position the lower limbs immediately adopt the characteristic position of adduction with the feet in equinus.

The upper limbs, where these were affected, were usually held in adduction and flexion, with the hand clenched or held in the obstetric position.

There were 17 cases of asymmetrical quadriplegia or triplegia. Some of these asymmetrical cases may have been examples of double hemiplegia.

There were 102 hemiplegics (60 right and 42 left). In nearly all these cases the upper limb was the more severely affected; it was usually held in the position described above.

In most spastics of all types there was some wasting of the affected limbs, which were both thinner and shorter than the normal ones in cases of hemiplegia. The usual signs of an upper motor neurone lesion were generally present: ' jack-knife' rigidity, exaggerated tendon jerks, and extensor plantar responses. The knee jerk was often so pronounced that it could be elicited by a tap anywhere along the edge of the tibia. The tendon jerks were exaggerated in 191 out of 290 spastics $(65.4 \%)$. In many of the cases where the jerks were normal or diminished in amplitude there were gross contractures. The plantars were extensor in 275 cases $(94.7 \%)$. Ankle clonus was uncommon. The abdominal reflexes were found to be unreliable signs of the presence or absence of an upper motor neurone lesion.

Athetosis (including Choreo-Athetosis and Chorea). These conditions will be considered together. In the typical athetoid there are irregular, serpentine involuntary movements at rest, which become worse when the child is nervous or selfconscious. In choreo-athetosis and chorea the movements are more jerky. Involuntary movements are seldom noticeable before the age of 18 months. The very young athetoid is usually limp and floppy; although involuntary movements at rest may be absent the child will reach for an object unsteadily, making several attempts to grasp it, the hand being held in the typical athetoid position of hyperextension at the metacarpophalangeal and flexion at the interphalangeal joints.

Older children with athetosis may subconsciously control the involuntary movements by becoming rigid, and these 'tension athetoids' are often diagnosed as spastics. In athetosis, however, the upper limbs are nearly always worse than the lower; unlike what is seen in spastic paralysis, the rigidity is not of the ' jack knife' type, the position of the hands is different, the tendon jerks are not exaggerated and the plantars are flexor. (None of our athetoids had exaggerated tendon jerks and only four had extensor plantars.)

In athetosis the involuntary movements affect muscles supplied by cranial nerves, leading to grimacing, slobbering, difficulties in swallowing and severe speech defects, all of which are rare in spastic paralysis, except among those of low intelligence. Even if there is no speech defect the protruded tongue often shows a writhing movement in athetosis, another distinction from spastic paralysis.

Athetosis nearly always affects both sides of the body equally, but we saw two cases of hemiathetosis, and occasionally one side may be a good deal worse than the other.

Mixed Cases. We saw 17 cases of combined athetosis and spastic paralysis, the upper limbs usually showing athetoid signs while the lower limbs were spastic.

Ataxia. There were four cases of ataxia, showing unsteady gait, pronounced intention tremor, muscular hypotonia, and flexor plantar responses. Other cerebellar signs, such as nystagmus and scanning speech, were absent in our cases.

Flaccid Cerebral Palsy. In two of our cases the limbs were flaccid and the tendon jerks diminished in amplitude; other signs, such as distribution of paresis, plantar responses, etc., were as seen in spastic quadriplegia.

Tremor and Rigidity. There was one case, that of a mentally defective girl aged 7 , in which tremor and rigidity of the Parkinsonian type were present.

The relative incidence of spastic paralysis and athetosis in our series is very different from that found by some recent writers (e.g., Phelps, 1941b; Evans, E., 1946; Collis, 1947; Evans, P., 1948), all of whom have found athetosis to be about as common as spastic quadriplegia. Other workers find that spastic paralysis is much the commoner, e.g., Yannet, 1944; McGovern and Yannet, 1947; Ford, 1944; McCarroll, 1949. Those who believe that athetosis is common stress the fact that 'tension athetoids' are commonly mistaken for spastics. Different criteria of diagnosis may be adopted by various workers. We consider that the following facts support our findings: (a) The physical signs 
displayed by our spastics were those usually considered typical of an upper motor neurone lesion. (b) The distribution of the lesions-in athetosis affecting chiefly the upper limbs and head-is characteristic, and helps to distinguish 'tension athetoids' from spastics. (c) Athetosis practically never spares the upper limbs completely, and so could not be confused with spastic paraplegia - in our series commoner than quadriplegia. Yet the paraplegics and quadriplegics clearly form a single group, and the dividing line between them is an arbitrary one. Some symptoms increase steadily in incidence from the mild paraplegics to the severe quadriplegics - for instance, microcephaly and low grade mental deficiency. Certain findings are common to both conditions; for example, the incidence of prematurity, of abnormal labour, of birth injury and asphyxia is almost identical among paraplegics and quadriplegics, and differs from that found among the athetoids.

Selection of cases may account for the different findings in different series. Our cases were unselected and included many low grade defectives (who were mostly spastic quadriplegics) and numerous cases of mild paraplegia and hemiplegia attending normal schools. Neither type of case is likely to be confused with athetosis; such cases were probably excluded from series such as that of Evans (1948), which consisted in part of children for whom admission to a special school for cerebral palsy cases was sought.

It is possible, however, that a diagnosis of combined athetosis and spastic paralysis should have been made more frequently, for, of nine spastic quadriplegics selected for admission to a special school for spastics in Birmingham, two developed athetoid symptoms after a period of treatment which resulted in a release of tension, and the diagnosis was altered to one of combined athetosis and spastic paralysis. On anatomical and pathological grounds it seems likely that the two conditions would often be associated, for either may be cortical in origin (Bucy and Buchanan, 1932; Bucy, 1942; Fulton, 1943).

\section{The Aetiology of Congenital Cerebral Paksy}

The following items in the history and clinical findings in our 349 cases may throw some light on the aetiology of cerebral palsy: family history, maternal age, maternal health during pregnancy, child rank, sex incidence, incidence of prematurity, incidence of twins, obstetric history, neonatal history, and serological signs of $\mathrm{Rh}$ incompatibility or syphilis.

Family History. In only one family did we find two cases of cerebral palsy: a family of four included a case of spastic quadriplegia and one of spastic paraplegia. In seven cases near relations were epileptic or mentally defective and three had siblings with congenital defects (polydactyly, webbed digits, and imperforate anus). All ten cases were spastic.

Matermal Age. Unfortunately this was not noted until towards the end of the series and the numbers are too small for analysis by diagnosis.

TABUE 3

Mother's Age at Birth of Affected Child (133 Cases)

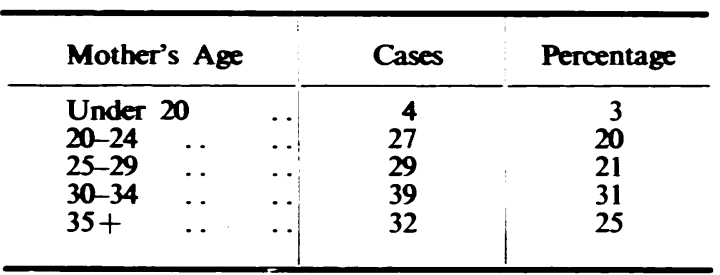

In Fig. 1 the distribution of maternal ages is compared with that found among legitimate maternities in England and Wales (Registrar General's Statistical Review for England and Wales, 1941). It will be noted that the mothers of children with cerebral palsy are, on the whole, older than the mothers of normal children.

Mother's Health dering Pregnancy. This was usually normal. There were 26 cases of toxaemia of pregnancy $(7 \cdot 4 \%)$, an incidence similar to that
among all pregnancies in Birmingham $(8 \% ;$ Dr. V. M. Crosse, personal communication). In 28 cases there was some other illness or accident during pregnancy, often of a trifling nature; there were four cases of threatened abortion and two cases of pneumonia during pregnancy; no mother had had any other infective disease, including rubella. In three cases the mother was a diabetic, a significant finding in view of the rarity of live births to diabetic mothers. (Fouracre Barns and Morgans, 1949, found that diabetes complicated one pregnancy in 580 at University College Hospital, and state that this is an unusually high proportion. The combined foetal and neonatal mortality among 58 cases was $55 \%$.)

Child Rank. One hundred and ninety-eight cases $(56.4 \%$ were first born. The Registrar General does not give the proportion of first born among all births in England and Wales but an approximate figure is obtained by adding all illegitimate births to legitimate first maternities. In 1941 such maternities comprised $47 \%$ of the total. The excess in our series is significant (S.E. 2-7). The incidence of first births in the different groups is given in Table 4; the differences are not statistically significant. 


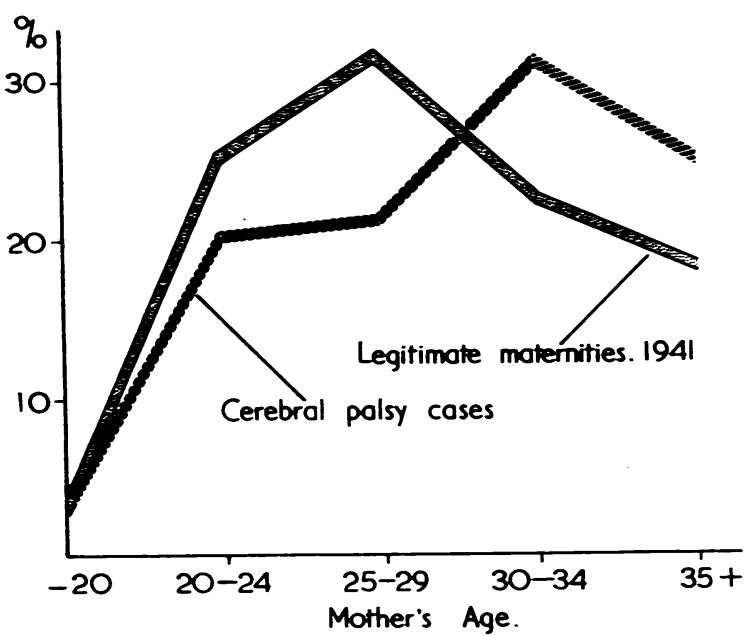

FIG. 1.-Graph showing age distribution among mothers of children with cerebral palsy and mothers of all legitimate infants (Midlands I: Registrar General's Statistical Review, 1941).

Out of 198 firstborns, $97(49 \%$ ), were only children, often because the mother had been afraid to have

TABLE 4

INCIDENCE OF FIRST BIRTHS

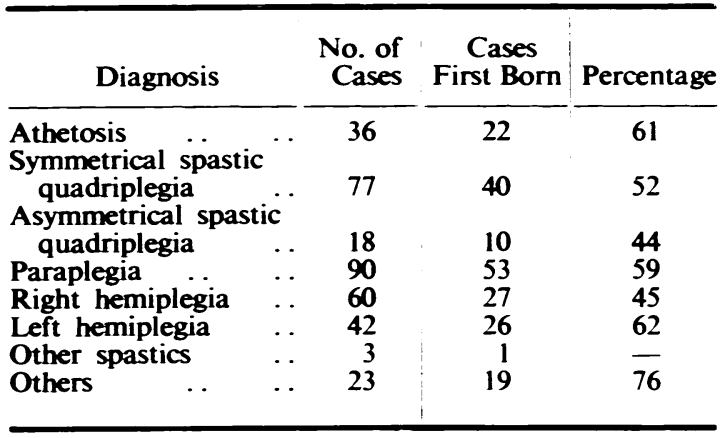

another baby for fear it might be similarly affected, or because the handicapped child required so much looking after.

Sex Incidence. There were 199 boys $(57 \%)$ and 150 girls $(43 \%)$ in our series. Among the general population $51 \cdot 3 \%$ of live births are males (Registrar General's Statistical Review, 1941). The excess of males in our series is on the borderline of statistical significance (S.E. 2-7). Table 5 gives the sex incidence in the different groups. Among all spastics there is a significant excess of males $(58.4 \%$, S.E. 2.9); although several sub-groups show a slight excess of males, the excess is significant only among the symmetrical quadriplegics (S.E. 5·7), where the male:female ratio is $2: 1$.

TABLE 5

SEX INCIDENCE

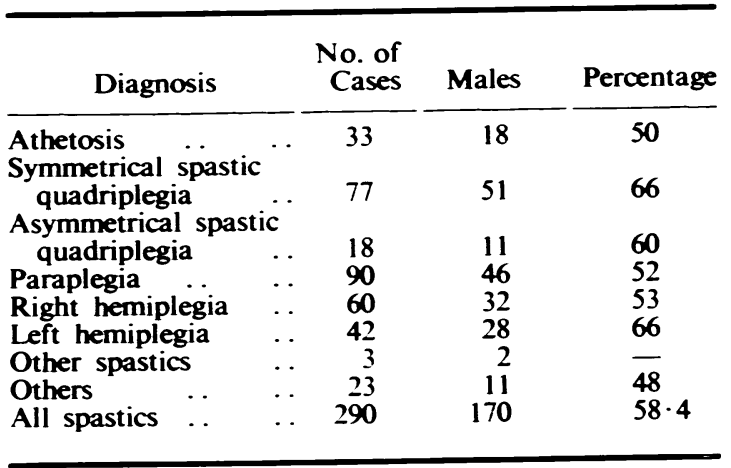

Incidence of Prematurity. In 128 cases $(39.4 \%)$ the birth weight was $5 \frac{1}{2} \mathrm{lb}$. or less. This is nearly eight times the percentage of prematurity among normal one-year-olds $(5 \%)$. The differences in incidence among the various groups are not statistically significant.

TABLE 6

Incidence of Prematurity by Diagnosis

\begin{tabular}{|c|c|c|c|c|}
\hline Diagnosis & & $\begin{array}{l}\text { No. of } \\
\text { Cases }\end{array}$ & $\begin{array}{l}\text { Premature } \\
\text { Cases }\end{array}$ & Percentage \\
\hline Athetosis ... & $\ldots$ & 36 & 10 & 28 \\
\hline $\begin{array}{l}\text { Symmetrical spastic } \\
\text { quadriplegia }\end{array}$ & & 77 & 35 & $45 \cdot 4$ \\
\hline $\begin{array}{l}\text { Asymmetrical spastic } \\
\text { quadriplegia }\end{array}$ & & 18 & 7 & 39 \\
\hline Paraplegia. & & 90 & 39 & $43 \cdot 9$ \\
\hline Right hemiplegia & .. & 62 & 17 & $27 \cdot 4$ \\
\hline Left hemiplegia & . & 42 & 14 & $33 \cdot 3$ \\
\hline Other spastics & . & 3 & 0 & $\overline{-}$ \\
\hline Others & & 23 & 6 & 28 \\
\hline
\end{tabular}

Incidence of Twins. Nineteen of these children were twins $(5.4 \%)$, more than four times the normal incidence $(1 \cdot 2 \%)$. This difference is highly significant (S.E. 0-26). In nine cases the twin sibling was normal; in ten the twin was stillborn or died soon after birth. In no cases were both twins affected.

The incidence of twins was highest among the spastic quadriplegics, symmetrical and asymmetrical; in the former group the incidence was significantly in excess of that among the general population (S.E. 3-6).

It is interesting to note that twinning is most frequent among mothers in the 30-34 age group 
TABLE 7

INCIDENCE OF TWINS

\begin{tabular}{|c|c|c|c|}
\hline Diagnosis & $\begin{array}{l}\text { No. of } \\
\text { Cases }\end{array}$ & $\begin{array}{l}\text { No. of } \\
\text { Twins }\end{array}$ & Percentage \\
\hline $\begin{array}{l}\text { Athetosis . } \\
\text { Symmetrical spastic }\end{array}$ & 36 & 0 & - \\
\hline $\begin{array}{l}\text { quadriplegia } \\
\text { Asymmetrical spastic }\end{array}$ & 77 & 8 & 11 \\
\hline quadriplegia & 18 & 3 & 16 \\
\hline Paraplegia . . & 90 & 3 & 4 \\
\hline Right hemiplegia & 60 & 2 & 3 \\
\hline Left hemiplegia & 42 & 2 & 5 \\
\hline
\end{tabular}

(Registrar General's Statistical Review for England and Wales, 1943). This is also the commonest age group in our series (Table 3 ).

Abnormal Labour. In considering the incidence of abnormal labour we have excluded premature babies because $(a)$ from the point of view of the premature infant no labour is normal, and (b) the mother often did not see her baby for days or weeks, and so could not report on its neonatal condition.

Among 221 deliveries of full term infants (i.e., those with a birth weight of over $5 \frac{1}{2} \mathrm{lb}$.) there were 87 abnormal labours $(39 \%)$. There were 53 cases of forceps delivery ( $24 \%)$. Thirty-four labours ( $15 \%)$ were otherwise abnormal (16 lasted 36 hours or over, five were precipitate, nine were cases of breech birth, two Caesarean sections, one severe haemorrhage, and one case of prolapsed cord). The forceps rate is $5 \%$ in Birmingham (Dr. V. M. Crosse, personal communication) with about $5 \%$ of other abnormalities of labour. Thus, abnormal labour was nearly four times as common in our series as among the general population. In 113 cases labour was normal and the mother received no anaesthetic or analgesic; in only 11 cases was the mother given any anaesthetic or analgesic during the course of a normal labour. In ten cases the obstetric history was unknown. A further analysis appears in Table 8.

Birth Injury and Asphyxia. This group includes babies who were blue or white at birth, those who could not suck or cry, those who had fits during the first days of life, those with severe external injury and those whom the mother was not allowed to see for many hours or days. Out of 221 full term babies $85(38 \%)$ had such symptoms (Table 9$)$.

Neonatal apnoea, cyanosis, feebleness, and convulsions might be caused by a poorly developed brain or by a brain damaged at birth. If birth injury is the cause of such symptoms we would expect them to be commoner after abnormal labours. In our series this was what we found. Among 87 children born after an abnormal labour $57(65 \cdot 5 \%)$ had signs of birth injury or asphyxia; out of 124 cases where labour was normal $28(22 \cdot 6 \%)$ showed such signs. In Table 8 these figures are further analysed. It will be seen that, except among cases of symmetrical quadriplegia, the majority of children born after an abnormal labour showed signs of birth injury or asphyxia, whereas the reverse is true of those where labour was normal.

TABLE 8

INCIDENCE Of BIRTh INUURy, etc., AFter AbNormal and Normal Labour

\begin{tabular}{|c|c|c|c|c|c|c|c|c|c|c|c|c|c|}
\hline \multicolumn{2}{|l|}{ Diagnosis } & & \multicolumn{5}{|c|}{ Abnormal Labour } & \multicolumn{5}{|c|}{ Normal Labour* } & \multirow[b]{2}{*}{$\begin{array}{c}\text { Obstetric } \\
\text { History } \\
\text { Unknown }\end{array}$} \\
\hline & & & \multirow[t]{2}{*}{ Total } & \multicolumn{2}{|c|}{$\begin{array}{l}\text { With } \\
\text { Birth Injury }\end{array}$} & \multicolumn{2}{|c|}{$\begin{array}{c}\text { Without } \\
\text { Birth Injury }\end{array}$} & \multirow[t]{2}{*}{ Total } & \multicolumn{2}{|c|}{$\begin{array}{l}\text { With } \\
\text { Birth Injury }\end{array}$} & \multicolumn{2}{|c|}{$\begin{array}{c}\text { Without } \\
\text { Birth Injury }\end{array}$} & \\
\hline & & & & No. & $\%$ & No. & $\%$ & & No. & $\%$ & No. & $\%$ & \\
\hline \multirow{2}{*}{\multicolumn{2}{|c|}{$\begin{array}{l}\text { Athetosis } \\
\text { Symmetrical quadri- } \\
\quad \text { plegia } \\
\text { Asymmetrical quadri- }\end{array}$}} & 26 & 17 & 12 & 60 & 5 & 40 & 8 & 2 & 25 & 6 & 75 & 1 \\
\hline & & 43 & 12 & 5 & 42 & 7 & 58 & 31 & 11 & 36 & 20 & 64 & $\mathbf{0}$ \\
\hline $\begin{array}{l}\text { plegia } . \\
\text { Paraplegia . } \\
\text { Right hemiplegia } \\
\text { Left hemiplegia } \\
\text { Other spastics } \\
\text { Others } \quad \text {. }\end{array}$ & $\begin{array}{l}\cdots \\
\cdots \\
\cdots \\
\cdots \\
\cdots\end{array}$ & $\begin{array}{r}11 \\
50 \\
43 \\
28 \\
3 \\
17\end{array}$ & $\begin{array}{r}3 \\
16 \\
16 \\
11 \\
0 \\
12\end{array}$ & $\begin{array}{r}3 \\
10 \\
10 \\
9 \\
0 \\
8\end{array}$ & $\begin{array}{r}100 \\
63 \\
63 \\
82 \\
0 \\
66\end{array}$ & $\begin{array}{l}0 \\
6 \\
6 \\
2 \\
0 \\
4\end{array}$ & $\begin{array}{r}0 \\
37 \\
37 \\
18 \\
0 \\
33\end{array}$ & $\begin{array}{r}8 \\
28 \\
26 \\
15 \\
3 \\
5\end{array}$ & $\begin{array}{l}1 \\
5 \\
3 \\
2 \\
1 \\
3\end{array}$ & $\begin{array}{l}12 \\
18 \\
12 \\
13 \\
33 \\
60\end{array}$ & $\begin{array}{r}7 \\
23 \\
23 \\
13 \\
2 \\
2\end{array}$ & $\begin{array}{l}88 \\
82 \\
88 \\
83 \\
66 \\
40\end{array}$ & $\begin{array}{l}0 \\
6 \\
1 \\
2 \\
0 \\
0\end{array}$ \\
\hline Total & $\ldots$ & 221 & 87 & 57 & $65 \cdot 5$ & 30 & $34 \cdot 5$ & 124 & 28 & $22 \cdot 6$ & 96 & $77 \cdot 4$ & 10 \\
\hline
\end{tabular}

- Including those where an anaesthetic was administered but labour was otherwise normal. 
Abnormal labour and birth injury were most common among athetoids; the incidence is significantly in excess of that in the whole series (S.E. 9-5). Among spastics, rather more hemiplegics than quadriplegics were born after an abnormal labour, but the differences are not statistically significant.

It is interesting to note that the athetoids show the largest percentage of abnormal labours (65) and the lowest percentage of premature babies (28); the opposite is true of the spastic quadriplegias $(28 \%$
Case 1. Girl, aged 2 years. Fifth of five children. Jaundiced at birth. Mild athetosis.

Father: A Rh+ R1/R1 CDe/CDe

Mother: $\mathbf{O} \mathbf{R h}+\mathbf{R} \mathbf{1} / \mathbf{r} \quad \mathrm{CDe} / \mathrm{cde}$

Child A Rh $+\mathbf{R} \mathbf{l} / \mathbf{r}$ CDe/cde ? anti A.

Case 2. Girl, aged 20 months. Second child. Jaundiced aged 2 days for one month. Severe athetosis.

Father: A1 R1/R2 CDe/cDE Kell ? positive. Mother: A1 R2/r cDE/cde Kell negative.

Child: A1 R1/R2 CDe/cDE Kell ? positive.

? anti Kell or anti C.

TABLE 9

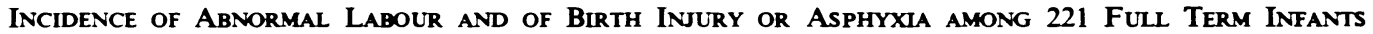

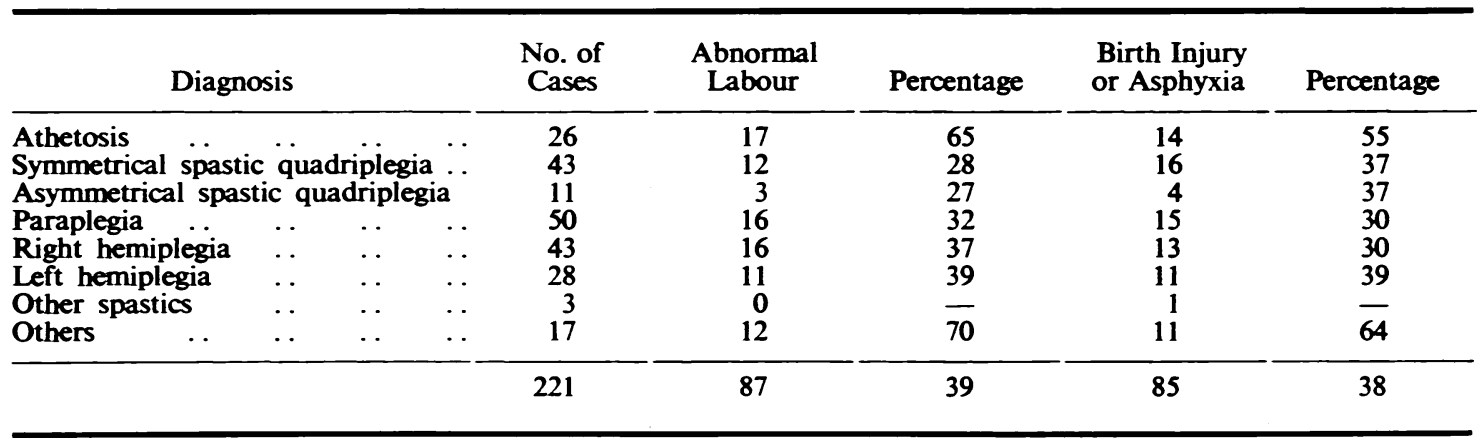

abnormal labours and $45.4 \%$ premature). This relationship is shown in Fig. 2.

Neonatal Jaundice. Twelve out of 36 athetoids $(33 \%)$ had a history of severe neonatal jaundice; only seven out of the remaining 313 cases had such a history. The cause of the jaundice in these cases is unknown; some may simply have had unusually pronounced physiological icterus. Among the athetoids five out of ten premature babies were jaundiced, whereas only four out of the remaining 118 premature babies were yellow.

Cases of known kernicterus due to $\mathbf{R h}$ iso-immunization will be discussed later; if we include these cases we find that out of 55 athetoids, 31 had a history of neonatal jaundice.

$\mathrm{Rh}$ tests were done in five of the 12 cases at present under consideration and gave no indication of ordinary $\mathbf{R h}$ incompatibility. Genotypes were determined in four of these cases. In two cases there was no incompatibility of any known factor; in the other two the blood groups were as follows:
Of the seven cases in which $\mathrm{Rh}$ tests were not carried out, four were first born. In only one of the remaining three cases did the history suggest kernicterus due to $R \mathbf{h}$ iso-immunization.

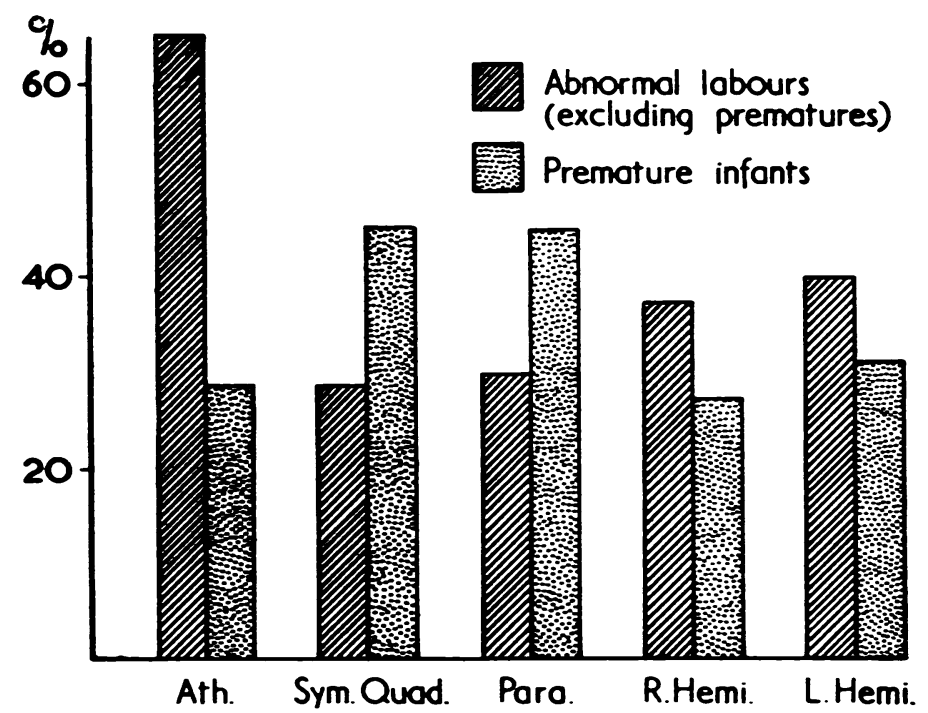

FIG. 2.-Diagram showing relationship between abnormal labour and cerebral palsy. 
In four cases of athetosis there was a history of birth injury or asphyxia as well as jaundice; in two of these labour was abnormal.

Rh Incompatibility. Rh tests were carried out in 75 unselected cases, apart from the 19 cases of kernicterus discussed later (13 athetoids, 56 spastics, and six others). In 66 cases $(88 \%)$ the mother's blood was $\mathbf{R h}+$ or both mother and child were $\mathbf{R h}-$. In nine cases $(12 \%)$ the mother was $\mathbf{R h}$ negative and the child $R h$ positive. This association is found in $8.2 \%$ of the general population. The difference is not statistically significant.

Syphilis. There were no clinical signs of congenital syphilis in any of these cases, and in 27 unselected cases (seven athetoids, 18 spastics, and two others) the blood Wassermann reaction was performed and found to be negative.

\section{Discussion}

More than a century ago Little first described the disease which bears his name, and noted that, in many cases of spastic paralysis, there was a history of abnormal labour. He considered that asphyxia, by causing 'capillary apoplexies,' was the cause of the brain damage. After nearly a century of controversy we are but little nearer to an understanding of cerebral palsy. All agree that, in many cases of cerebral palsy, there is a history of premature birth, difficult labour, or neonatal signs such as asphyxia, convulsions, feeble cry and inability to suck. Lumbar punctures on such infants often reveal bloodstained fluid (Roberts, 1939) and even normal babies may have bloody cerebrospinal fluids (Sharpe and Maclaire, 1924).

When birth-injured babies die at or soon after birth, intracranial haemorrhage is commonly found; the subject is discussed in detail by Craig (1938). Asphyxia at birth produces multiple petechial haemorrhages in the brain and other organs, but there is no evidence that such petechiae cause permanent ill effects in surviving children (Ford, 1926; 1944). Schwartz (1927) found that punctate haemorrhages into the grey matter surrounding the ventricles were common in babies dying soon after birth, and were associated with engorgement of the veins of the Galenic system. This engorgement he attributed to pressure changes inside the skull, such as occur even during a normal labour.

Can such findings be correlated with the postmortem appearances of the brain in cases of cerebral palsy dying many years after the supposed birth injury? Here we find no agreement. Freud (1897), Collier (1924), Grulee (1936) and many others reject the birth injury theory. Patten and Matthews (1935), Stewart (1942), Ford (1944), and McGovern and Yannet (1947) consider that birth injury rarely causes symmetrical spastic paralysis, although it may cause hemiplegia. Alpers and Marcovitz (1938), however, state that the post-mortem findings in a proportion of cases are compatible with a traumatic aetiology. Benda (1945) studied the neuropathology in 24 cases and considered that his findings supported the birth injury theory.

In cases of symmetrical spastic paralysis (quadriplegia and paraplegia) the commonest pathological findings are those of cerebral agenesis and atrophic lobar sclerosis (Ford, 1944). The former is generally accepted as a state of arrested neural development and the latter as a degenerative condition. Alpers and Marcovitz (1938) consider that the degenerative changes could be the result of trauma, inflammation or vascular occlusion, whether intrauterine, natal, or post-natal in origin, but many others (e.g., Collier, 1924) disagree. One of the difficulties in accepting birth trauma as the cause of many cases of 'Little's disease' is the fact that the paralysis is usually symmetrical, whereas birth haemorrhage is nearly always asymmetrical in distribution (Craig, 1938; Ford, 1944). However, Benda (1945) stresses the fact that a symmetrical paralysis may be associated with an asymmetrical pathological lesion.

In hemiplegia and other forms of asymmetrical paralysis porencephaly may be found, and this may be attributed to vascular accidents, at birth or otherwise. Bilateral porencephaly may also be found in cases of symmetrical paralysis.

In athetosis the lesion is commonly situated in the basal ganglia, although the cerebral cortex is usually affected too. 'Marbling' of the corpus striatum in athetosis was first described by Vogt and Vogt (1920). The marbling (status marmoratus) is produced by a network of myelinated nerve fibres surrounding paler islands of glial cells and fibres. Benda (1945) found that marbling of the basal ganglia was often associated with cortical vascular lesions, and quotes experimental work to show that, in animals, such marbling may follow removal of the cortex. Norman (1947) described three cases in which status marmoratus appeared to be attributable to birth injury. He relates the characteristic distribution of the marbling to the engorgement of the Galenic venous system often found in babies dying of birth injury (Schwartz, 1927), for these veins drain the basal ganglia. It is noteworthy that, in two of his cases, gross cortical lesions were also present.

It would seem that the part played by birth injury in the aetiology of cerebral palsy could best be estimated by following up a large number of birthinjured babies, but few such follow-ups have so far been published. Roberts (1939) described the findings in 66 cases of proved intracranial birth 
haemorrhage, followed up for periods of up to 15 years. Fourteen of these cases had a residual mental and/or motor defect; there were nine cases of spastic paralysis associated with mental defect, and four had motor defects alone. It is instructive to note that only two of these 14 cases were Negroes, although, in a series of many thousand births he found that Negro infants were just as susceptible to intracranial haemorrhage as white. This suggests that genetic, as well as traumatic, factors are involved. Roberts quotes other workers who found that congenital abnormalities of the nervous and other systems were rare among Negroes.

A much larger series has been studied by Professor W. S. Craig(see page 325). Over a period of 17 years he personally examined 593 newborn babies with signs of intracranial irritation due to birth trauma and followed them up for periods of up to five years. In 56 cases he found residual mental and/or physical defects, including 41 cases of cerebral palsy (17 hemiplegics, five asymmetrical quadriplegics, eight monoplegics, two diplegics, four cases of hydrocephalus, and five of athetosis or ataxia). The preponderance of asymmetrical palsies is noteworthy. Thus it would appear that, whereas many consider that congenital hemiplegia and, perhaps, athetosis, may be the result of birth injury, symmetrical spastic paralysis is more often believed to be the result of genetic or intrauterine causes. What these causes are remains a mystery. Evidence of genetic abnormality is rare, and so is a history of maternal illness or injury during pregnancy.

Aetiological Evidence from this Series

This is based on the history and clinical findings in 349 cases. We found that a history of prematurity, difficult birth or a stormy neonatal period, was very common, thus confirming other workers' findings. Thus, in 128 cases $(39.4 \%)$ the birth weight was $5 \frac{1}{2} \mathrm{lb}$. or less, and, of the remaining 221 cases, $87(39 \%)$ were born after an abnormal labour and $85(38 \%)$ had signs of neonatal asphyxia or injury. Few mothers had any anaesthetic or analgesic if labour was normal, suggesting that drugs were not in themselves important in this series. There were more firstborns, more twins, more children of older mothers, and rather more boys than would be expected in a random sample of the general population.

These figures are more helpful when further analysed. We then find that the incidence of abnormal labour and a stormy neonatal period is higher among athetoids than spastics. On the other hand, the sex incidence and the incidence of twins among the athetoids is similar to that among the general population, whereas, among spastics, we found more boys and more twins than would be expected by chance. The excess of males is most marked among the spastic quadriplegics, where there were twice as many boys as girls.

More spastics than athetoids were premature babies, but the difference is not significant. Nor is the difference in incidence of firstborns; the maternal age was not recorded often enough for an analysis to be of value.

These figures suggest that birth injury more often causes athetosis than spastic paralysis, thus confirming the findings of Evans (1948). The high incidence of males among the spastics, especially among the spastic quadriplegics, suggests the possibility of a congenital defect in many of these cases, for most congenital defects have a predeliction for one sex or the other. (Thus, in hydrocephalus the male: female ratio is $1: 27$; in spina bifida it is $0: 7$-Woolf, 1946.) Similarly, twins have a higher than normal incidence of congenital defects, and twins were commoner among spastics than athetoids.

The frequent history of prematurity among cerebral palsy cases has been variously explained. Premature babies are more liable than full term to suffer intracranial damage. Freud (1897), however, suggested that some congenital abnormality caused both the brain defect and the premature onset of labour. This view is supported by the high incidence of congenital abnormalities among premature infants; thus Crosse (1949) found that $5.7 \%$ of premature and $0.8 \%$ of full term infants (live and stillborn) had congenital abnormalities. In our series prematurity was more common among spastics than athetoids, and, though the difference is not statistically significant, it is at least suggestive that the group with the greatest incidence of birth-injured babies had the smallest percentage of premature infants and vice versa.

Among spastics we found no definite evidence that birth injury is more likely to cause an asymmetrical than a symmetrical paralysis, unlike most other workers (e.g., Ford, 1926; McGovern and Yannet, 1947; Craig, 1950). The incidence of prematurity, abnormal labour and birth injury was not significantly different among the various types of spastic paralysis. Similarly, we did not confirm Ford's findings that hemiplegics usually have larger heads than children with symmetrical spastic paralysis, which he considers to be additional evidence that hemiplegia is more often traumatic, symmetrical paralysis, developmental, in origin. We found that, on average, the worse the paralysis the smaller the head, irrespective of the symmetry of the lesion. Thus, more than half our spastic quadriplegics had small heads, compared with $27 \%$ of hemiplegics and $19 \%$ of paraplegics. 
If it is agreed that spastic paralysis is often the result of causes operating before birth we still have no notion what these causes may be. There is little evidence of genetic factors-the incidence of associated congenital abnormalities is not excessive, and a family history of any central nervous or other congenital defect is rare. There is no unusual incidence of any maternal illness during pregnancy, except of diabetes, which may have caused three cases in our series-all, incidentally, cases of asymmetrical spastic paralysis. Maternal age may be a factor, for elderly mothers are more likely to give birth to abnormal infants (e.g., mongols) but, on the other hand, an elderly mother is also more likely to have an abnormal labour. We found no evidence that syphilis causes cerebral palsy, nor difference in $R h$ group in the absence of frank haemolytic disease of the newborn.

Finally, there is the remarkable incidence of neonatal jaundice among athetoids in our series. Excluding 19 cases of known kernicterus, there was a history of severe jaundice at or soon after birth in 12 out of 36 cases of athetosis $(33 \%)$ and in only seven out of the remaining 313 cases. If cases of known kernicterus are included we find that there was a history of jaundice in 31 out of 55 athetoids $(56 \cdot 6 \%)$. Although $\mathrm{Rh}$ iso-immunization could not be excluded in all 12 cases, it was absent in the five cases where $R h$ tests were done, and, in two of the four cases where genotypes were determined, there was no incompatibility of any known factor. This suggests that the neurological complications of icterus neonatorum are not peculiar to cases of $\mathrm{Rh}$ incompatibility and cannot therefore be the result of antibody fixation in the tissues. The jaundice itself, or the hepatic insufficiency of which it is the sign, appears to cause the nuclear damage which results in athetosis. This confirms the findings of Baar (1945) who described two infants in whom post-mortem examination showed liver damage and necrotic foci in the central nervous system without erythroblastosis or $\mathbf{R h}$ incompatibility. One infant was jaundiced, the other was not; in the nonjaundiced case the nuclear lesions were similar to those found in kernicterus, but bile staining was absent. He concludes that 'kernicterus' is a hepatic encephalopathy, and that the bile staining is secondary to the nuclear necrosis. Findlay, Higgins, and Stanier (1947) have shown that 'physiological icterus' is due to hepatic insufficiency, not to excessive haemolysis, so it is possible that the hepatic defect may, in some cases, be sufficient to damage the brain.

To sum up: our evidence suggests that congenital athetosis is, in most cases, the result of damage to the brain at, or soon after, birth, associated with either birth injury or neonatal jaundice. Congenital spastic paralysis may be the result of unknown antenatal causes, or of birth trauma or, perhaps, of both.

\section{B. ACQUIRED CEREBRAL PALSY}

\section{Kernicterus}

There were 19 cases of athetosis or choreoathetosis following icterus gravis neonatorum, in which the serology and family history were typical of haemolytic disease of the newborn. These are described as cases of kernicterus. In the present series the blood of every child was $\mathrm{Rh}$ positive, the mother being $R \mathbf{h}$ negative. In ten cases the mother's serum contained anti $R h$ agglutinins and blocking antibodies; in seven cases blocking antibodies only were found and two had neither agglutinins nor blocking antibodies. In every case there was at least one normal, elder sibling; in eight families other siblings had been affected.

The symptoms and signs in these cases differed in no way from those of the other athetoids already described. Every degree of severity was seen, from that of a helpless, bedridden idiot to an attractive little girl with scarcely perceptible movements and an I.Q. of 100. There was no correlation between the severity of the neonatal jaundice and that of the central nervous defect.

It is unlikely that, in other series, such a large proportion of athetoids would prove to be cases of kernicterus (19 out of 55 cases, i.e., $34 \%$ ). A number of our cases were young children with mild athetosis referred to us by Dr. Gerrard, who was following up cases of haemolytic disease of the newborn. Some of these cases would probably have been missed had the neonatal history not led to this follow-up.

\section{Post-meningitic Cerebral Palsy}

There were nine cases of paralysis following an illness diagnosed as meningitis; two other cases of progressive hydrocephalus and paralysis of obscure origin may also have been post-meningitic and are here included.

The meningitis in two cases was meningococcal; there were two cases of pneumococcal and one of $H$. influenzae meningitis. In three cases no organism was discovered in the cerebrospinal fluid: two of these cases had a lymphocytic pleocytosis. In the remaining case no details concerning the original illness were available.

Hydrocephalas. Five of these nine cases were hydrocephalic; they had all had meningitis under the age of six months, whereas the non-hydrocephalic cases had been over six months old at the time of the illness. 
Type of Paralysis. The hydrocephalics all had a paraplegia or quadriplegia; the four remaining cases included two hemiplegics, one paraplegic, and one case of quadriplegia. The paralysis was spastic in every case.

Fits. Two of these children had frequent generalized convulsions; one had had a series of fits seven years after the original illness.

Intelligence. Probably all these children were mentally retarded, though in three cases the I.Q. was not yet assessable. Three children were low grade mental defectives. Further details are given in Table 10.

In five of our cases spastic paralysis followed an attack of purulent meningitis during the first 15 months of life. Such a sequel to meningitis is, fortunately, uncommon. Matthews (1949) followed up 42 children who had had meningitis, treated with sulphonamides, in infancy or early childhood; only one had developed spastic paralysis. He concludes that the sulphonamides have not only reduced the mortality of meningococcal meningitis, but they have also improved the outlook for those that survive. It is noteworthy that only two of our cases had had meningococcal meningitis, although our survey covered those whose infancy had been passed in the epidemic years 1940 and 1941. Braid and Meyer (1949) described 15 cases of $H$. influenzae meningitis treated with sulphadiazine and penicillin or streptomycin. Of the 12 who recovered one developed spastic paralysis (our Case 5), and she had been ill for 14 to 21 days before treatment was begun. Similarly, one of our meningococcal cases had had no specific treatment for several days, owing to delay in making the diagnosis. It is unfortunate that the insidious onset of some cases of meningitis in infancy makes early diagnosis difficult, for it appears that purulent meningitis, promptly diagnosed and treated with the appropriate sulphonamide or antibiotic, is unlikely to cause permanent brain damage.

In two of our cases (Nos. 6 and 7) paralysis

TABLE 10

Analysis of Nine Cases of Post-meningitic Cerebral Palsy

\begin{tabular}{|c|c|c|c|c|c|c|c|c|}
\hline Case & Sex & $\begin{array}{c}\text { Age of } \\
\text { Onset of } \\
\text { Meningitis } \\
\text { (months) }\end{array}$ & C.S.F. & Treatment & $\begin{array}{l}\text { Present } \\
\text { Condition }\end{array}$ & $\begin{array}{l}\text { Hydro- } \\
\text { cephalus }\end{array}$ & Fits & I.Q. \\
\hline 1 & M. & 4 & $\begin{array}{l}\text { Purulent: } \\
\text { meningococci }\end{array}$ & Sulphapyridine & $\begin{array}{l}\text { Paraplegia, fits, } \\
\text { helpless }\end{array}$ & Yes & Yes & Idiot \\
\hline 2 & M. & $2 \underline{\underline{1}}$ & $\begin{array}{l}\text { Purulent: } \\
\text { meningococci }\end{array}$ & 'Sulphonamides ' & Quadriplegia & Yes & No & $\begin{array}{l}\text { Not yet } \\
\text { assessable }\end{array}$ \\
\hline 3 & F. & 3 & $\begin{array}{l}\text { Purulent; } \\
\text { pneumococci }\end{array}$ & Sulphapyridine & Paraplegia & Yes & $\begin{array}{l}\text { On } \\
\text { one } \\
\text { occa- } \\
\text { sion }\end{array}$ & 65 \\
\hline 4 & $\mathbf{F}$. & 8 & $\begin{array}{l}\text { Purulent; } \\
\text { pneumococci }\end{array}$ & $\begin{array}{l}\text { Sulphonamides; } \\
\text { systemic and } \\
\text { intrathecal } \\
\text { penicillin }\end{array}$ & Left hemiplegia & No & No & $\begin{array}{l}\text { Not yet } \\
\text { assessable }\end{array}$ \\
\hline 5 & F. & 7 & $\begin{array}{l}\text { 1,000 cells, Ptn } 340 . \\
H . \text { influenzae }\end{array}$ & $\begin{array}{l}\text { Penicillin; } \\
\text { sulphadiazine }\end{array}$ & $\begin{array}{l}\text { Quadriplegia; } \\
\text { fits }\end{array}$ & No & Yes & Low \\
\hline 6 & F. & 6 & $\begin{array}{l}\text { Sterile; } 400 \text { cells, } \\
61 \% \text { lymphocytes. } \\
\text { Cl. 655, Ptn } 150 .\end{array}$ & $\begin{array}{c}\text { Sulphamerazine }+ \\
\text { soluseptasine }\end{array}$ & Paraplegia & Yes & No & 73 \\
\hline 7 & F. & 15 & $\begin{array}{l}\text { Sterile; } 310 \text { lym- } \\
\text { phocytes }\end{array}$ & Sulphonamides & Right hemiplegia & No & No & 80 \\
\hline 8 & $\mathbf{M}$ & 3 & Sterile; (no details) & Sulphapyridine & $\begin{array}{l}\text { Quadriplegia; } \\
\text { very severe }\end{array}$ & Yes & No & $\begin{array}{l}\text { Probably } \\
\text { low }\end{array}$ \\
\hline 9 & M. & 12 & Unknown & Unknown & Paraplegia & No & No & 84 \\
\hline
\end{tabular}


followed an illness diagnosed clinically as meningitis in which the C.S.F. showed a lymphocytic pleocytosis. Acute lymphocytic meningitis nearly always runs a benign course and such sequels must be very rare. Hence a retrospective diagnosis of encephalitis might be considered in such cases. In epidemic encephalitis Type B (e.g., St. Louis encephalitis, Japanese encephalitis) meningitic symptoms occur, the C.S.F. shows an excess of lymphocytes (rarely exceeding 250 cells per c.mm.), and spastic paralysis has been reported in survivors, although very rarely (Ford, 1944). Post-mortem studies show that the disease is a meningo-encephalitis, and it is possible that Case 7, with its modest pleocytosis ( 310 lymphocytes per c.mm.) and residual hemiplegia, may have had a disease of this nature. In Case 6, however, where there were $\mathbf{4 0 0}$ cells per c.mm. in the C.S.F., and where hydrocephalus and paraplegia developed, invasion of the meninges by an unknown agent must be assumed.

\section{Doubtful Post-meningitic Cerebral Paky}

Case 1. A two-year-old girl began to walk unsteadily; paralysis of the legs gradually developed and later the head began to enlarge. When seen at the age of 2 years 10 months she could not walk; there was spastic paralysis of the legs, marked hydrocephalus, and blurring of the optic discs. The C.S.F. was under increased pressure and contained 20 white cells per c.mm. A ventriculogram showed internal hydrocephalus. The child progressively deteriorated and was sent home, no treatment being of any avail. Diagnosis: ? chronic post-basic meningitis.

Case 2. A boy aged 14 months developed a complete paralysis of the left sixth and seventh cranial nerves. The C.S.F. was normal. The head began to enlarge. Two years later spastic paraplegia gradually developed. At the age of 7 the condition now appears to be stationary; he has a head circumference of $23 \frac{1}{2}$ in., complete left sixth and seventh cranial nerve palsies and moderately severe paraplegia. His I.Q. is 75 .

These two might be described as cases of ' arachnoiditis.' Ford (1946) discusses this illdefined condition. The term is applied to cases of hydrocephalus of obscure causation, often complicated by cranial nerve palsies and spastic paralysis; there may or may not be a history of some ill-defined febrile illness at the onset. At operation or necropsy proliferation and adhesions of the leptomeninges are found, with resultant cyst formation. Subclinical meningitis, otitis media, and trauma have at different times been blamed.

\section{Cerebral Paky of Infective Origin (exchuting Meningitis)}

Case 1. A baby girl developed normally till the age of 8 months, when she had cervical adenitis and bronchopneumonia. She then seemed to 'flop' completely; before that she had been sitting up well. She is now 12 years old, very unsteady, and cannot walk unsupported; there is an intention tremor of the hands. The I.Q. is below $\mathbf{5 0}$.

Diagnosis: ? cerebellar ataxia of toxic or infective origin.

Case 2. A girl of 7 had a severe attack of poliomyelitis (of which no details are available); before that she had developed normally. When seen one year later the right arm was spastic, the left flaccid and wasted. Both legs were wasted with absent knee jerks but marked ankle clonus and extensor plantar responses. Her I.Q. was 95.

\section{Acute Infantile Hemiplegia}

There were 12 cases of acute infantile hemiplegia of unknown causation, and two cases of hemiplegia occurring during the course of measles and diphtheria (Table 11).

The former group of 12 cases included seven girls and five boys. Six were firstborn. Seven were born at term after a normal labour; three were born prematurely and two suffered from birth injury or asphyxia after an abnormal labour. Thereafter the children developed normally for a year or two, except in two cases; in one of these there was a doubtful history of dragging the affected foot, in the other the affected hand appeared to be weak in the early stages. In all twelve cases a fit, or series of fits during the first or second year, was the first definite symptom of cerebral mischief, and in each case occurred when the child seemed to be in good health. Usually the hemiplegia became apparent as the child emerged from the first series of convulsions, but in three cases repeated fits occurred before paresis developed. In two of these cases lasting hemiplegia developed after a fit of unusual severity; in the third case the child had repeated attacks of left-sided convulsions followed by a transitory left hemiplegia; after two or three years the paralysis gradually became more persistent and finally a mild hemiplegia was permanently established. In every case except the last the paralysis was most severe at its onset, and thereafter improved or remained stationary.

The residual physical and mental handicap was severe in most cases. The hemiplegia was severe or moderate. Eleven out of 12 children continued to have fits after the hemiplegia was established (compared with $24 \cdot 2 \%$ of congenital hemiplegics); 
both generalized and Jacksonian convulsions occurred. One case had a left-sided hemianopia. Out of 11 children whose intelligence could be tested, ten were moderately or severely defective.

\section{Hemiplegia Associated with Specific Fevers}

There were two of these. One girl had measles at the age of 18 months; while the rash was still out she had a series of right-sided convulsions lasting 48 hours, after which a right hemiplegia became apparent. The second case was that of a girl who had severe faucial diphtheria at the age of 7 years. On the eighth day she collapsed with signs of acute heart failure. Next day she was found to have a right hemiplegia and speech was difficult. The paralysis improved while she was in hospital but defective speech and mentality were noted on discharge. She was later found to have left optic atrophy and right hemianaesthesia; occlusion of the left internal carotid artery must have occurred. This was the only case in the series where the hemiplegia was not ushered in by fits; Jacksonian convulsions developed some years later.

\section{Discussion}

The aetiology of infantile hemiplegia has long been a matter for argument; the literature is summarized by Ford and Schaffer (1927) and Wyllie (1948).

In our series the history in most cases suggests a vascular catastrophe rather than encephalitis as the cause of the hemiplegia. Thus, the sudden onset in a healthy child, the paralysis (in all but one case) which is maximal when first apparent, the normal cerebrospinal fluid (in the four cases in which it was examined) are all suggestive of a vascular rather than an encephalitic origin. Arterial occlusion may also have caused the two cases of hemiplegia which occurred during specific fevers. The diphtheritic case may have had an arterial embolism secondary to a cardiac thrombosis. (Ford found in the literature reports of necropsies on 21 diphtheric cases; cerebral embolism was found in 13 of them.) Cerebral arterial thrombosis may have caused the hemiplegia in the measles case, for other arteries are known to be thrombosed in severe cases of measles. However, the fact that in five out of our twelve

TABLE 11

Analysis of 14 Cases of Acute Infantile Hemiplegia

\begin{tabular}{|c|c|c|c|c|c|c|c|c|}
\hline Sex & $\begin{array}{l}\text { Child } \\
\text { Rank }\end{array}$ & Birth History & $\begin{array}{l}\text { Infection } \\
\text { at Onset }\end{array}$ & $\begin{array}{l}\text { Age at } \\
\text { Onset of } \\
\text { Fits }\end{array}$ & $\begin{array}{c}\text { Age at } \\
\text { Inset of } \\
\text { Hemiplegia }\end{array}$ & $\mathbf{L} / \mathbf{R}$ & $\begin{array}{l}\text { Persistent } \\
\text { Fits }\end{array}$ & I.Q. \\
\hline F. & 1 & Normal & None & 10 mths. & 10 mths. & $\mathbf{R}$ & Yes & 51 \\
\hline F. & 2 & Premature & None & 18 mths. & 3 yrs. & $\mathbf{L}$ & Petit mal & 67 \\
\hline F. & 1 & Forceps; asphyxia & None & 2 yrs. & 4 yrs. & $\mathbf{R}$ & Yes & 60 \\
\hline F. & 4 & Normal & None & 18 mths. & 18 mths. & $\mathbf{R}$ & Occasional & 91 \\
\hline F. & 3 & Premature & None & 2 yrs. & 2 yrs. & $\mathbf{L}$ & $\begin{array}{l}\text { Petit mal and } \\
\text { grand mal }\end{array}$ & 59 \\
\hline F. & 4 & Normal & None & 15 mths. & 15 mths. & $\mathbf{R}$ & Occasional & 85 \\
\hline F. & 10 & $\begin{array}{l}\text { Caesarean section; } \\
\text { baby not expected } \\
\text { to live }\end{array}$ & None & 14 mths. & $\begin{array}{l}14 \text { mths. } \\
\text { (after 2nd } \\
\text { fit) }\end{array}$ & $\mathbf{R}$ & Yes & 62 \\
\hline $\mathbf{M}$. & 1 & Normal & None & 20 mths. & 20 mths. & $\mathbf{L}$ & Yes & 53 \\
\hline $\begin{array}{l}\mathbf{M} \\
\mathbf{M}\end{array}$ & $\begin{array}{l}6 \\
1\end{array}$ & $\begin{array}{l}\text { Premature } \\
\text { Normal }\end{array}$ & $\begin{array}{l}\text { None } \\
\text { None }\end{array}$ & $\begin{array}{l}18 \text { mths. } \\
15 \text { mths. }\end{array}$ & $\begin{array}{l}18 \text { mths. } \\
15 \text { mths. }\end{array}$ & $\begin{array}{l}\mathbf{R} \\
\mathbf{R}\end{array}$ & $\begin{array}{l}\text { Yes } \\
\text { Petit mal }\end{array}$ & $\begin{array}{l}48 \\
46\end{array}$ \\
\hline M. & 1 & Normal & None & 18 mths. & 18 mths. & $\mathbf{L}$ & No & $\begin{array}{l}\text { Not yet } \\
\text { assessable }\end{array}$ \\
\hline M. & 1 & Normal & None & 2 yrs. & 5 yrs. & $\mathbf{L}$ & Jacksonian & 84 \\
\hline F. & 2 & Normal & Measles & 18 mths. & 18 mths. & $\mathbf{L}$ & Jacksonian & 62 \\
\hline F. & 4 & Normal & Diphtheria & 10 yrs. & 7 yrs. & $\mathbf{R}$ & Jacksonian & 48 \\
\hline
\end{tabular}


non-infective cases there was a history of prematurity or birth injury is suggestive, and it is possible that, in these cases, there was some brain damage of natal or prenatal origin which did not manifest itself until a year or two later. Moreover, in two cases there was a doubtful history of some weakness of hand or foot before the onset of the hemiplegia. To sum up: our cases suggest that acute infantile hemiplegia is the result of a vascular accident of unknown cause; it is po:sible that in some cases some intracranial abnormality has been present from birth.

\section{Progressive Degenerative Spastic Paralysis}

There were four of these cases, of which one was familial. In a second case it was too early to say whether or not the disease would affect other members of the family.

In all four cases the child appeared to develop normally for the first few years of life, when weakness of the legs became gradually noticeable. From then on the disease progressed steadily or in jerks, until a severe degree of mental and physical defect was present.

\section{Cerebral Palsy following a Head Injury}

A girl of 3 years had a depressed fracture of the skull and developed a left hemiplegia. When seen by us at the age of 12 the paresis was mild and her I.Q. was 85 .

\section{THE PSYCHOLOGICAL AND EDUCATIONAL ASPECTS OF THE SURVEY}

From a psychological point of view the aims of this research were to obtain an estimate of the distribution of intelligence in the group of cerebral palsied children; to use the experience of giving individual psychological tests to approximately $\mathbf{4 0 0}$ children of varying degrees of physical disability to furnish a background from which certain tentative suggestions could be made for dealing with this problem, one of the most difficult in mental testing; to obtain an estimate of the general reading attain- ment of the group, by giving a standardized reading test to all children capable of responding.

\section{The Selection of Cases}

Of the $\mathbf{4 0 0}$ cases submitted for medical examination all, except two, between the ages of 3 and 15 years inclusive, were also seen by the psychologist.

Experience throughout the survey tended to confirm our original policy of caution in forming definite estimates of intelligence for young severely handicapped cerebral palsy children and for most of those who had not yet reached their third birthday. There were a number whose early history suggested that the child would be mentally defective, and indeed a few, who had actually been certified, were later proved to be of normal or slightly subnormal intelligence. In such, not only do the parents suffer unnecessary anxiety, but often the children are deprived of full opportunity to develop latent powers because it is considered waste of time to enrich their restricted environment. For these reasons, therefore, children under 3 years of age have not been included, although some were tested (Table 12).

Assessing the Intelligence of the Cerebral Paksied Child

Assessing the intelligence of cerebral palsied children is a more difficult task than testing the intelligence of normally equipped pupils. It requires more time, patience, and understanding of the psychological background and attitudes of this particular type of child. Special attention has been given to: (1) selection of a suitable intelligence test; (2) observation of the child as an individual-his physical disabilities, opportunities for learning, past experience, ability to express himself, general behaviour in the test situation and at home; (3) adherence to testing techniques as far as possible; (4) interpretation of test results in the light of other information gained; (5) original assessments of intellectual levels to be regarded as tentative estimates which should be revised if later experience

TABLE 12

Distribution According to Age and Sex of 354 Cases of Cerebral Palsy

\begin{tabular}{|c|c|c|c|c|c|c|c|c|c|c|c|c|c|c|}
\hline $\begin{array}{c}\text { Age } \\
\text { (Years) }\end{array}$ & 3 & 4 & 5 & 6 & 7 & 8 & 9 & 10 & 11 & 12 & 13 & 14 & 15 & Total \\
\hline Boys & 19 & 13 & 28 & 17 & 11 & 8 & 26 & 15 & 23 & 8 & 6 & 9 & 10 & 193 \\
\hline Girls & 14 & 16 & 25 & 16 & 12 & 8 & 16 & 14 & 11 & 10 & 10 & 4 & 5 & 161 \\
\hline Total & 33 & 29 & 53 & 33 & 23 & 16 & 42 & 29 & 34 & 18 & 16 & 13 & 15 & 354 \\
\hline
\end{tabular}


suggests this is advisable, an important step with very young and/or severely handicapped children; (6) intelligence quotients, where given, are basal estimates.

Selection of a Suitable Intelligence Test. There is at present no ideal test for this purpose but the one found most suitable was the Stanford-Binet Intelligence Scale. It should be noted that the verbal element of the test limits its usefulness with those children who have speech difficulties, the performance and written requirements restrict those with hand disabilities or incoordination, and the items to some extent dependent on scholastic attainment penalize those who have been denied educational facilities. It is not improbable, too, that the Scale is weighted with the kind of experience which the normal child absorbs by moving about in his environment, and which is denied to many handicapped children. Appreciating these limitations, experience with the Stanford-Binet test suggests that if it is administered with understanding and interpreted with caution, a reliable estimate of intellectual potentiality may be obtained in the majority of cases. This does not include the very young or very severely handicapped.

In this survey it was possible to obtain estimates of intelligence for 340 of the 354 children between the ages of 3 years and 15 years. Of the 14 for whom it was impossible to obtain estimates, all except one were very severely handicapped. In no such case was a performance or non-verbal test possible. The 354 cases did not include a single case where the child had severely affected speech combined with good hand coordination.

\section{Test Procedure}

All except ten were interviewed by the same psychologist. This interview was carefully planned and the same procedure was followed throughout the survey, every effort being made to obtain complete rapport and to dispel any anxiety or tension likely to be associated with the situation. Whenever possible the mother was asked to withdraw while the psychological test was in progress, but when such a course seemed prejudicial to the success of the test the mother was allowed to remain in the room. In the testing of cerebral palsied children an important feature appears to be flexibility in handling the human situation involved while maintaining a strictly scientific attitude towards the administration of the test.

\section{Results of the Psychological Interview}

In a very large proportion of the cases it was possible to give a fairly definite basal estimate of the child's intellectual level. For example, it could be safely said that a certain child's I.Q. was at least 85. Sometimes the actual I.Q. would be somewhat higher, as in the case of a child whose test score was adversely affected by lack of experience at school or one who failed on verbal tests owing to difficulties of speech. In this work it was felt

TABLE 13

Distribution of 354 Estimated I.Q.s of Cerebral Palsy Group Compared with Normal Child Population

\begin{tabular}{|c|c|c|c|c|c|}
\hline I.Q. Level & $\begin{array}{l}\text { No. of } \\
\text { Cases }\end{array}$ & $\begin{array}{l}\text { o of } \\
\text { Group }\end{array}$ & $\begin{array}{l}\% \text { Normal } \\
\text { Population }\end{array}$ & $\begin{array}{c}\text { Usual } \\
\text { Nomenclature }\end{array}$ & $\begin{array}{r}\text { Suitable } \\
\text { Provision }\end{array}$ \\
\hline $130+$ & 2 & $0 \cdot 6$ & 1 & \multirow{2}{*}{ Supernormal } & \multirow[b]{5}{*}{$\begin{array}{l}\text { Special } \\
\text { school for } \\
\text { E.S.N. }\end{array}$} \\
\hline $110-129$ & 12 & $3 \cdot 4$ & 22 & & \\
\hline $90-109$ & 71 & $20 \cdot 1$ & 52 & Normal & \\
\hline $70-89$ & 95 & $26 \cdot 8$ & 22 & Dull & \\
\hline $50-69$ & 81 & $22 \cdot 9$ & \multirow{3}{*}{3} & $\begin{array}{l}\text { Feebleminded } \\
\text { or Moron }\end{array}$ & \\
\hline $25-49$ & 38 & $10 \cdot 7$ & & Imbecile & $\begin{array}{l}\text { Occupation } \\
\text { centre }\end{array}$ \\
\hline Below 25 & 41 & $11 \cdot 6$ & & Idiot & Ineducable \\
\hline Not yet assessable & 14 & $3 \cdot 9$ & & & \\
\hline
\end{tabular}


necessary to present the picture as we saw it, and since there is always danger in estimating what improvement 'might be made' under certain circumstances we decided that our estimates of intelligence should be made with caution. Hence the estimates given herein as basal figures may be accepted with confidence.

As will be seen from Table 13 and Fig. 3 in the cerebral palsy group $51 \%$ have I.Q.s over 70, and $23 \%$ I.Q.s between 50 and 69 . While the extremely bright group (I.Q.130-) is not markedly smaller in the cerebral palsy sample than in the normal population, the group of normal and supernormal intelligence as a whole form only $24 \%$ of the cases as against $75 \%$ in the normal population. Conversely, at the bottom end of the intelligence scale, $45 \%$ of the cerebral palsy group have I.Q.s under 70 whilst only $3 \%$ of the ordinary population are in this category.

Correlation of

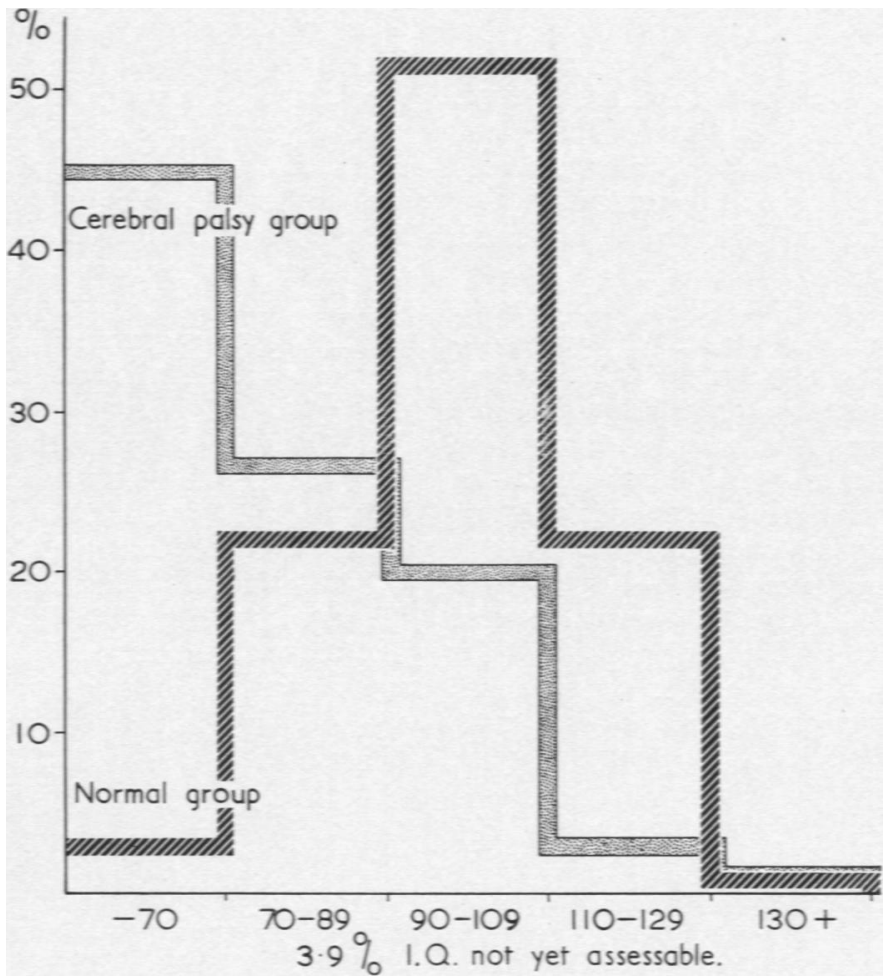

FIG. 3.-Distribution of 354 estimated I.Q.s of cerebral palsy group compared with distribution of those of normal child population.
Results from First and Second Testing. Twenty children, aged from 5 to 11 years, admitted to the Carlson House School for Spastics were given a re-test 12 months after the original testing. These children were selected for the school as being particularly in need of specialized education and treatment and therefore would be more likely to present testing problems than many of the less handicapped. Moreover, of the six whose two I.Q. findings differed by more than 7 points, five were severely handicapped physically as well as having additional severe sight and/or speech defects. It would seem, therefore, that while the Stanford-Binet test gave fairly accurate indications of the children's intellectual levels with the moderately handicapped it could only be taken as a rough estimate when
TABLE 14

\begin{tabular}{|c|c|c|c|}
\hline & Mean I.Q. & S.D. & N. \\
\hline Original Test & $87 \cdot 7$ & $12 \cdot 69$ & 20 \\
\hline Re-test after 12 months & $89 \cdot 8$ & $17 \cdot 09$ & 20 \\
\hline
\end{tabular}

used with severely handicapped children. Nevertheless, although emphasis has been laid upon the discrepancies in the test-retest results, these are the exception rather than the rule.

Table 14 gives the means and standard deviations of the results of the two sets of tests.

Table 14 shows that there was no significant increase or decrease in the mean I.Q.S of the group tested, but there were certain cases where a significant difference in the I.Q.s on the two tests was noted. Three of these were so marked as to warrant special mention.

Case 1. A severely handicapped athetoid boy, $10 \frac{1}{2}$ years old, when first tested was a pupil at a residential school for cerebral palsied children and his basal I.Q. was assessed at 112. He appeared to be unhappy living away from his parents and was admitted to Carlson House, which is a day school, in January, 1949. When retested after four months at Carlson House and 12 months after his first test his I.Q., was recorded as 133 . There seems little doubt that the original testing was

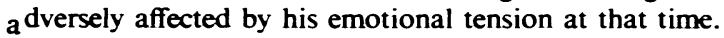

Case 2. This was a slightly handicapped spastic girl of $6 \frac{1}{2}$ years who was attending a school for the physically handicapped. Eight months after transfer to Carlson House her I.Q. had risen from 100 to 126 . In this case it seems likely that at the school for physically handicapped children she was not getting the intellectual stimulus she needed.

Case 3. This was a severely handicapped athetoid 
girl, nearly 6 years old. Her lack of speech and inability to use her hands rendered her original testing extremely difficult. Her I.Q. was estimated to be approximately 103. Twelve months later and after three months at Carlson House her responses on retesting were almost identical with those on the original testing and her I.Q. was 88. A possible explanation of this result may be that she found it difficult suddenly to respond overtly to stimuli after three months of almost total physical inactivity which had been the treatment prescribed for her.

\section{Relation of Intelligence to the Various Forms of Cerebral Palsy}

Table 15 shows the mean estimated I.Q.s of 277 spastics, 41 athetoids, four ataxics, and 18 cases of mixed type. The mean I.Q.s vary but little with the different types of cerebral palsy, the greatest difference being 5.6 points between the spastics and the ataxics. These differences are not statistically significant. Hence we may assume that in the sample

TABLE 15

Mean Estimated I.Q. OF 340 Children Grouped According to Form of Cerebral Palsy

\begin{tabular}{|c|c|c|c|c|c|}
\hline & Spastic & Athetoid & Ataxic & Mixed & Total \\
\hline Mean I.Q. & $67 \cdot 9$ & $67 \cdot 6$ & $62 \cdot 3$ & $62 \cdot 4$ & \\
\hline S.D. & $27 \cdot 7$ & $25 \cdot 5$ & $19 \cdot 3$ & $21 \cdot 5$ & \\
\hline N. & 277 & 41 & 4 & 18 & 340 \\
\hline $\begin{array}{l}\text { Not yet } \\
\text { assessable }\end{array}$ & 9 & 4 & - & 1 & 14 \\
\hline Total N. . . & 286 & 45 & 4 & 19 & 354 \\
\hline
\end{tabular}

of cerebral palsied cases examined in this survey there is no significant difference between the mean I.Q.s of the groups characterized by different forms of the handicap. In this connexion it is interesting to note that Phelps (1941b) reports a higher level of intelligence among athetoids than among spastics. Evans (1946) also found that less than $10 \%$ of the athetoids and over $60 \%$ of the spastics at Carshalton Hospital were ineducable, but from such a small group of only 47 cases, drawn from a wide area, it is, however, unsound to draw general conclusions.

Table 16 gives a further analysis of the first column of Table 15. The pure spastics have been grouped according to the type of spastic paralysis, and this table shows the mean estimated I.Q.s of 41 left hemiplegics, 57 right hemiplegics, 85 paraplegics, and 80 quadriplegics. Monoplegics and triplegics are omitted. While there are no statistically significant differences in mean I.Q. between the two kinds of hemiplegics and the paraplegics, there is
TABLE 16

Mean Estmated I.Q. OF 263 Children Groupei according to Category of Spastic Paralysis

\begin{tabular}{|c|c|c|c|c|c|}
\hline & $\begin{array}{l}\text { Left } \\
\text { Hemi- } \\
\text { plegia }\end{array}$ & $\begin{array}{l}\text { Right } \\
\text { Hemi- } \\
\text { plegia }\end{array}$ & $\begin{array}{l}\text { Para- } \\
\text { plegia }\end{array}$ & $\begin{array}{l}\text { Quadri- } \\
\text { plegia }\end{array}$ & Total \\
\hline Mean I.Q. & $77 \cdot 9$ & $76 \cdot 8$ & $74 \cdot 3$ & $50 \cdot 2$ & \\
\hline S.D. & $20 \cdot 1$ & $26 \cdot 0$ & $23 \cdot 6$ & $27 \cdot 6$ & \\
\hline N. & 41 & 57 & 85 & 80 & 263 \\
\hline $\begin{array}{l}\text { Not yet } \\
\text { assessable }\end{array}$ & 1 & 2 & 2 & 4 & 9 \\
\hline Total N. . & 42 & 59 & 87 & 84 & 272 \\
\hline
\end{tabular}

evidence in the whole table of a gradual decline from left hemiplegics to right hemiplegics, to paraplegics, and the group of quadriplegics is markedly, and significantly, lower still.

\section{TABLE 17}

Mean estimated I.Q. Of 354 Cerebral Palsied Children Grouped According to Degree of Physical DISABIITY

\begin{tabular}{|c|c|c|c|c|c|}
\hline & $\begin{array}{l}\text { Slight } \\
\text { Handi- } \\
\text { cap }\end{array}$ & $\begin{array}{l}\text { Moder- } \\
\text { ate } \\
\text { Handi- } \\
\text { cap }\end{array}$ & $\begin{array}{c}\text { Severe } \\
\text { Handi- } \\
\text { cap }\end{array}$ & $\begin{array}{c}\text { Very } \\
\text { Severe } \\
\text { Handi- } \\
\text { cap }\end{array}$ & Total \\
\hline Mean I.Q. & $81 \cdot 8$ & $71 \cdot 7$ & $55 \cdot 6$ & $24 \cdot 6$ & \\
\hline S.D. & $19 \cdot 96$ & $23 \cdot 74$ & $25 \cdot 50$ & $16 \cdot 98$ & \\
\hline N. & 87 & 148 & 85 & 20 & 340 \\
\hline $\begin{array}{l}\text { Not yet } \\
\text { assessable }\end{array}$ & 2 & 2 & 8 & 2 & 14 \\
\hline Total & & & & & 354 \\
\hline
\end{tabular}

Table 17 gives the mean estimated I.Q.s of 340 cerebral palsied children grouped according to the degree of physical disability. Only one child in the very severely handicapped group showed signs of normal intelligence. He was a little boy of 5 years of age who had been in hospital for a long time. He could not use his legs, he could not speak, and he had practically no use of his hands, yet from his general reactions to stimuli and to certain selected intelligence test items it was concluded that he probably had almost average intelligence. This opinion was confirmed by the hospital staff.

An examination of the figures given in Table 17 shows that there is a significant correspondence between the level of intelligence and the degree of physical disability. All the differences between these 
mean I.Q.s are statistically significant. This does not, however, imply that this is so in every individual case. There is a considerable overlap between the groups as can be seen from the wide standard deviations; some of our most intelligent children are in the groups of moderately and severely handicapped; on the other hand there are a number whose chief handicap is mental impairment, with only very slight physical disability.

\section{Reading Test}

Each child capable of reading was given the Schonell Graded Word Test (Schonell, 1945) to ascertain his level of reading attainment as measured by norms for the general school population. From this the reading age was obtained and the reading quotient computed. Our examination of the figures obtained for the 113 children in the reading group shows that $80 \%$ had reading quotients of 80 or more. These figures, however, obscure the fact that whereas some older children of mediocre intelligence and slight physical handicap obtain comparatively high reading quotients through the advantage of more years at school, a considerable number of the brighter children, who have had limited or no schooling on account of their physical disabilities, obtain low reading quotients. They have not had sufficient opportunity to use their intellectual powers to the full. Further analysis suggests that while under the present educational provision cerebral palsied children of I.Q. 70 - can be taught to read fairly effectively, the normally intelligent and very bright cerebral palsied child tends to be given insufficient opportunity and stimulus to develop his abilities beyond mediocre levels.

\section{SLMMARY AND CONCLUSIONS}

A survey of cases of cerebral palsy among children in the Midlands is described.

Four hundred cases were examined; the group appeared to be a representative sample of all types of cerebral palsy.

The incidence of cerebral palsy among the school-age population of certain towns is probably about 1 per 1,000 .

Among 349* cases of congenital cerebral palsy there were 290 cases of spastic paralysis $(83 \%)$, 36 athetoids $(10 \%), 17$ mixed cases $(5 \%)$, three cases of ataxia, two of flaccid paralysis, and one of rigidity and tremor. The relative incidence of spastic paralysis and athetosis is discussed, with

* Since this paper was written, one of us (P.A.) has seen 83 more cases. There were 74 cases of congenital cerebral palsy of which 55 were spastic (quadriplegia 16, paraplegia 14, and hemiplegia 25), 14 athet oid, and five mixed. The other nine cases comprise seven cases of kernicterus, one of acute infantile hemiplegia, and one of acquired extrapyramidal rigidity (? due to toxoplasmosis). The findings in these cases were comparable to those of the previous 400 . special reference to the figures given in other published series.

The aetiology of congenital cerebral palsy is discussed. Evidence from this series suggests that athetosis is usually the result of birth injury or asphyxia or of neonatal jaundice, whether due to $\mathrm{Rh}$ iso-immunization or not. Birth injury probably causes some cases of spastic paralysis, while others are the result of genetic or intrauterine factors.

We found no evidence that asymmetrical spastic paralysis is more likely to be due to birth injury than to symmetrical paralysis.

Fifty-one cases of acquired cerebral palsy were examined. These comprised 19 cases of kernicterus, 14 of acute infantile hemiplegia, 11 post-meningitic palsies, two other infective cases, four cases of progressive spastic paralysis, and one of posttraumatic hemiplegia. The aetiology of acute infantile hemiplegia is discussed; it is suggested that vascular accidents are the usual cause of this condition.

All but two cases over the age of 3 years were examined by a psychologist and the intelligence was assessed in all but 14 cases, using the method of Stanford-Binet (T.M.L.). The I.Q. was 70 or over in $51 \%$ of cases, between 50 and 69 in $23 \%$, and below 50 in $26 \%$.

No significant difference in the mean I.Q. of spastics and athetoids was found.

The mean I.Q. of the various groups varied inversely with the severity of the physical handicap; thus the mean I.Q. of spastic quadriplegics was significantly lower than that of the hemiplegics or paraplegics.

An examination of the attainment in reading of the normally intelligent and bright children reveals a very considerable degree of retardation. This suggests that, unless special educational provision is made, many cases will lack the stimulus necessary to develop their capacities beyond mediocre levels.

Many people cooperated in this survey, without whose help it could not have been carried out. Professor Smellie has given us unfailing help and encouragement. Professor Schonell helped in planning the psychological part of the work. Dr. Baar did the Rh tests and gave much valuable advice. Dr. W. D. Wall and Dr. M. M. Johnstone checked the statistics. The medical officers of health of Coventry, Kidderminster, Nuneaton, Stoke-on-Trent, and Walsall lent us premises for our clinics and their staff assisted us. The medical, nursing, and teaching staff of hospitals, special schools and mental deficiency institutions allowed us to examine cases on the premises and gave us every assistance. Mrs. Davey undertook the voluminous secretarial work involved and Miss Woodall helped with administration. To all these, and to the many doctors who referred cases to us, we offer our warm thanks and appreciation. Part of the expenses of this investigation were defrayed from a grant from Messrs. Cow and Gate Ltd. 


\section{REFERENCES}

Alpers, B. J., and Marcovitz, E. (1938). Amer. J. Dis. Child., 55, 356.

Baar, H. S. (1945). Austrian med. Bull., 1. Special issue, p. 1.

Barns, H. H. Fouracre, and Morgans, M. E. (1949). Brit. med. J., 1, 51.

Benda, C. E. (1945). Medicine, Baltimore, 24, 71.

Braid, F., and Meyer, R. B. (1949). Brit. med. J., 2, 11.

Bucy, P. G. (1942). J. Neuropath. exp. Neurol., 1, 224. and Buchanan, D. N. (1932). Brain, 55, 479.

Collier, J. (1924). Ibid., 47, 1.

Collis, E., 1947. Lancet, 2, 239.

Craig, W. S. (1938). Archives of Disease in Childhood, $13,89$.

Craig, W.S. (1950). Archives of Disease in Childhood,25, 325.

Crosse, V. M. (1949). ' The Premature Baby,' 2nd ed. London.

Evans, E. S. (1946). Proc. R. Soc. Med., 39, 317.

Evans, P. R. (1948). Archives of Disease in Childhood, 23, 213.

Ford, F. R. (1926). Medicine, Baltimore, 5, 121.

- (1944). 'Diseases of the Nervous System in Infancy, Childhood and Adolescence.' 2nd ed. Springfield, Illinois.

- , and Schaffer, A. J. (1927). Arch. Neurol. Psychiat., Chicago, 18, 323

Findlay, L., Higgins, G., and Stanier, M. W. (1947). Archives of Disease in Childhood, 22, 65.
Freud, S. (1897). 'Die infantile Cerebrallähmung.' In Speciellen Pathologie und Therapie, ed. Nothnagel, H., Vol. 9. Wien.

Fulton, J. F. (1943). 'Physiology of the Nervous System.' 2nd. ed. New York.

Grulee, C. G. (1936). Amer. J. Dis. Child., 52, 648.

McCarroll, H. R. (1949). J. Amer. med. Ass., 140, 1231.

McGovern, J., and Yannet, H. (1947). Amer. J. Dis. Child., 74, 121.

Malpas, P. (1937). J. Obstet. Gynaec. Brit. Emp., 44, 434.

Matthews, J. D. (1949). Lancet, 2, 149.

Norman, R. M. (1947). Journal of Neurology, Neurosurgery and Psychiatry, 10, 12.

Patten, C. A., and Matthews, R. A. (1935). Arch. Neurol. Psychiat., Chicago, 34, 61.

Phelps, W. M. (1941a). N.Y. St. J. Med., 41, 1827. (1941b). Sth. med. J., Bgham., Ala., 34, 770.

Roberts, M. H. (1939). J. Amer. med. Ass., 113, 280.

Schonell, F. J. (1945). 'The Psychology and Teaching of Reading.' Edinburgh.

Schwartz, P. (1927). Ergebn. inn. Med. Kinderheilk., 31, 165.

Sharpe, W., and Maclaire, A. S. (1924). Surg. Gynec. Obstet., 38, 200.

Stewart, R. M. (1942). Proc. R. Soc. Med., 36, 25.

Vogt., C., and Vogt, O. (1920). J. Psychol. Neurol., Lpz., 25, 660.

Woolf, B. (1946). Brit. med. Bull., 4, 170.

Wyllie, W. G. (1948). Proc. R. Soc. Med., 41, 459.

Yannet, H. (1944). J. Pediat., 24, 38. 